which more than 100 researchers from eight Community countries are involved, is the study of plankton in the Antarctic seas organized by the Alfred Wegener Institute at Bremerhaven, in West Germany. Material was collected from the research vessel Polarstern during the Antarctic summer just completed, but its analysis will take a further two years (to which the Commission will contribute $551,000 \mathrm{ECU})$. And six marine science laboratories plan to study Quaternary sedimentation in the North Sea by means of a series of boreholes and with the help of a 1.51 million ECU grant over two years.

Among the grants CODEST did not make last year is that to which Nature has given some publicity - the proposal by the European VLBI consortium of radioastronomers that the Commission should finance its plan for the re-equipment of the collaborating observatories and also support the proposed centre for the analysis of VLBI data at a cost of 17.8 million ECU.

In reality, the VLBI proposal would have consumed the whole of the SCIENCE budget for a year. The issue that remains to be decided is not whether the SCIENCE programme must be enlarged, but whether the Commission should devise a new mechanism for meeting such requests, which is subsidiary to the question of what the Commission's role in basic research is judged to be.

With all that said, in its small way, SCIENCE seems to enjoy a degree of flexibility not common in the Commission's works. Being small no doubt helps, but so does the advisory committee called CODEST which ultimately decides which projects shall succeed. (First, there is a refereeing procedure.) As if in recompense for its time and trouble in cutting up the small cake, CODEST has the right to be consulted about all proposals for developments in science and technology making their way to the Commission.

The chairman of CODEST since 1987 is Sir Peter Swinnerton-Dyer, chairman of the British University Grants Committee until that was transmogrified into the Universities Funding Council, of which he is now the chief executive. Unlike most of the Commission's advisory committees, CODEST members are not representatives of their governments but independent persons, which also gives the committee more legitimacy than that attaching to groups of government nominees.

Given the influence of CODEST in the Commission's scheme of things, as well as its independence, it is probably the institution in the EEC best placed to raise the important question of what the balance between basic and applied research should be. There is not much time left for tackling the question: the next Framework programme will be upon us before we know.

\title{
Where to go next?
}

\section{Brussels}

ONE key figure in shaping the future pattern of the Commission's support of research and development is Dr Paolo Fasella, the Italian who has been directorgeneral of DGXII for long enough to command the respect of a substantial part of European science. He is emphatically not a bureaucrat, but an he is an enthusiast.

Last month, Fasella was basking in the outcome of the council meeting on 14 March. The decisions taken then bring to 98 per cent the proportion of the current Framework programme budget which has been approved (but some projects still have to work their way through the parliament). There is now a sense of expectation as people ask themselves what will follow. Will the expected increase of the budget from 1,500 million to 2,500 million ECU by the end of 1991 materialize?

The same meeting of the research council approved one of Fasella's favourite projects - that of using Community funds ( 30 million ECU by the end of 1991) to make better use of major installations scattered through the Community. The starting-point is the calculation that pieces of equipment as different as radiotelescopes and synchrotron light sources may be under-used because those for whom they were built do not, or no longer, use them fully. A synchrotron, for example, may have been equipped with fewer outlets on its circumference than can be accommodated.

Under the new scheme, operators of large EEC installations may be given grants with which to upgrade them, on condition that the equipment is then made available to researchers elsewhere in the EEC or, at first, elsewhere in Europe. Support will be provided for periods of three to five years. DGXII's hope is that it will soon have some 30 installations on its books.

On the more distant future, Fasella believes that the programmes of industrial research support will continue, even multiply, but that the Commission will find itself paying more attention to the needs of basic research. He says that many of DGXII's research activities, not simply its occasional grants to the European Science Foundation, help to form durable networks of people, which could usefully be multiplied.

H. J. Allgeier, director of the division responsible for planning and evaluation in DGXII and a strong advocate of the nascent aeronautics programme, goes further, acknowledging that it may not be long before the Commission has to face up to the responsibility of "standing behind" research institutions such as CERN and the European Space Agency (ESA). But at this stage, nobody seems willing to go to the stake for turning the Commission's research programme into EEC's public grant-making agency.

It is not easy to see how this question will get the hearing within EEC that its importance demands. Most member governments are worried about their own economic performance in relation to that of other member states and also share the general view that competing with the United States or Japan (or both) is what EEC is for. They take the simple view that backing industrial research makes sense, but at the same time value the ability (or illusion) of seeming to shape national policy which national grant-making agencies can provide.

It is also the case that the Commission is not constitutionally well-suited to the role of a grant-making agency dedicated to the support of basic research and the pursuit of excellence. There would be obvious political difficulties if the research grants awarded by the Commission's hypothetical grant-making agency were not pro rata with member states' estimates of their national importance (by the yardstick of population, GDP or whatever). More seriously, most well-judged research grants would be discriminatory, not involving transnational collaboration, which the Commission is meant to foster.

There are nevertheless two directions in which the Commission could usefully feel out the ground ahead. First, it is anomalous that the Commission has so little direct concern with skill training and higher education; direct support of basic research might be a useful entrée.

Second, it would be entirely consistent with the Commission's present function that it should play a direct part in supporting collaborative research institutions, CERN, ESA and the smaller fry. Member governments would suspect that to be a way of spending their money by proxy and with less attention than they would exercise themselves, but there are many formulae by which the obvious dangers could be avoided. Why not make a few experiments? The VLBI proposal (page 720) would be a natural starting-point.

Commission support for basic research in member states might also be held germane to the Commission's function if it were regarded as one of the means by which economic imbalances within EEC might be in the long run corrected. There is already a Social Fund providing palliative cash. Why not research funds as well? Given that less prosperous member states' ability and readiness to spend money on basic research will always be deficient, the Commission's intervention may be the only sure way of increasing the general level of research spending in the Community. 